\title{
Complication of laser-induced thermal therapy for Baker's cyst
}

\author{
S.A. Chernyadiev ${ }^{1}$, V.B. Aretinskiy ${ }^{2}$, A.V. Zhilyakov ${ }^{3}$, N.Yu. Korobova ${ }^{1}$, S.M. Kutepov ${ }^{1}$ \\ ${ }^{1}$ Ural State Medical University, Ekaterinburg, Russian Federation \\ ${ }^{2}$ State Autonomous Health Institution of the Sverdlovsk Region „Chusovsky Lake” Regional Specialized Centre of Medical Rehabilitation, \\ Ekaterinburg, Chusovsky Lake Settlement, Russian Federation \\ ${ }^{3}$ New Technologies for Outpatient Medicine Ltd. (“NOTAMED” LTD), Ekaterinburg, Chusovsky Lake Settlement, Russian Federation
}

\begin{abstract}
Interventional laser-induced thermal therapy (LITT) is an emerging technique to treat popliteal synovial cysts. The goal of LITT is coagulation and subsequent obliteration of inosculation and cystic cavity under local tumescent anesthesia. Ultrasound is an imaging method used for LITT. Analyzing the results of the use of laser obliteration of Baker's cyst, the authors concluded that obliteration of solely the cystic popliteal cavity can provide persistent recovery. As expected, in any invasive procedure, there are some procedure-related adverse events or complications.
\end{abstract}

Keywords: Baker's cyst; laser-induced thermal therapy; complication

\section{INTRODUCTION}

Baker's cyst is a benign synovial mass. The prevalence of the condition among patients seen for knee pains ranges from 3.4 to $32.0 \%$ [1, 2]. There is no single approach to surgical strategy due to specific anatomical location of the entity, vague etiology and pathogenesis [3]. Local laser hyperthermia is used at several outpatient clinics employing collagen denaturation through exposure to direct radiation or secondary heat emittance [4]. The authors used the practice for laser obliteration of Baker's cyst [5]. and detected several shortcomings and difficulties during surgical interventions în addition to ease and efficacy of the technique. For instance, laser settings were produced empirically for local photocoagulation of the connective tissues and often appeared being not optimal with poorly predictable results. The procedure was associated with a risk of complication including burn of subcutaneous fat tissue due to difficultiues of ultrasound visualization of the fine light pipe through soft tissues [6].

\section{MATERIAL AND METHODS}

A 51-year-old female patient presented with complaints of intermittent cramps of gastrocnemius and episodes of sharp pain at the back of the left knee joint followed by tibial edema 2 months ago. She was examined at the Ekaterinburg office of ZAO Phlebology Center (Head of department O.A. Vinogradov, Când.Sci.(Med)). Palpation of the popliteal spaces behind the left knee joint revealed percutaneous elastic solid mass sized $4 \times 2 \mathrm{~cm}$. No changes în the skin was detected over the entity. Moderate crepitus was noted with passive motion of the left knee. Foucher sign was negative. Twodimensional sonographic evaluation was performed for differential diagnosis using the B-mode Sonos 2000 ultrasound machine (HewlettPackard, USA) and 5.0 to $7.5 \mathrm{MHz}$ linear ultrasonic probe.

\section{RESULTS}

Ultrasound physician detected elliptically contoured liquid mass (Fig. 1) $1 \mathrm{~cm}$ deep with hyperechoic capsule 1.0-1.5 mm thick having heterogeneous hypoechoic structure due to singular parietal proliferation of $2 \mathrm{~mm}$ with no signs of loose or fixed chondral bodies. The entity sized $42 \times 30 \times 11 \mathrm{~mm}$. The liquid inside the cavity was echolucent. The mass squeezed with compression using the transducer and the contents did not appear to evacuate în the articular cavity.

The patient was diagnosed with left-sided grade I-II gonarthrosis and Baker's cyst. The findings were helpful for identifying surgical solution and laser induced thermal therapy was offered for the patient who provided written informed consent. Contraindications were ruled out after preoperative examination and tests and the date of intervention fixed.

Chernyadiev S.A., Aretinskiy V.B., Zhilyakov A.V., Korobova N.Yu., Kutepov S.M. Complication of laser-induced thermal therapy for Baker's cyst. Genij Ortopedii, 2020, vol. 26, no 1, pp. 95-98. DOI 10.18019/1028-4427-2020-26-1-95-98 

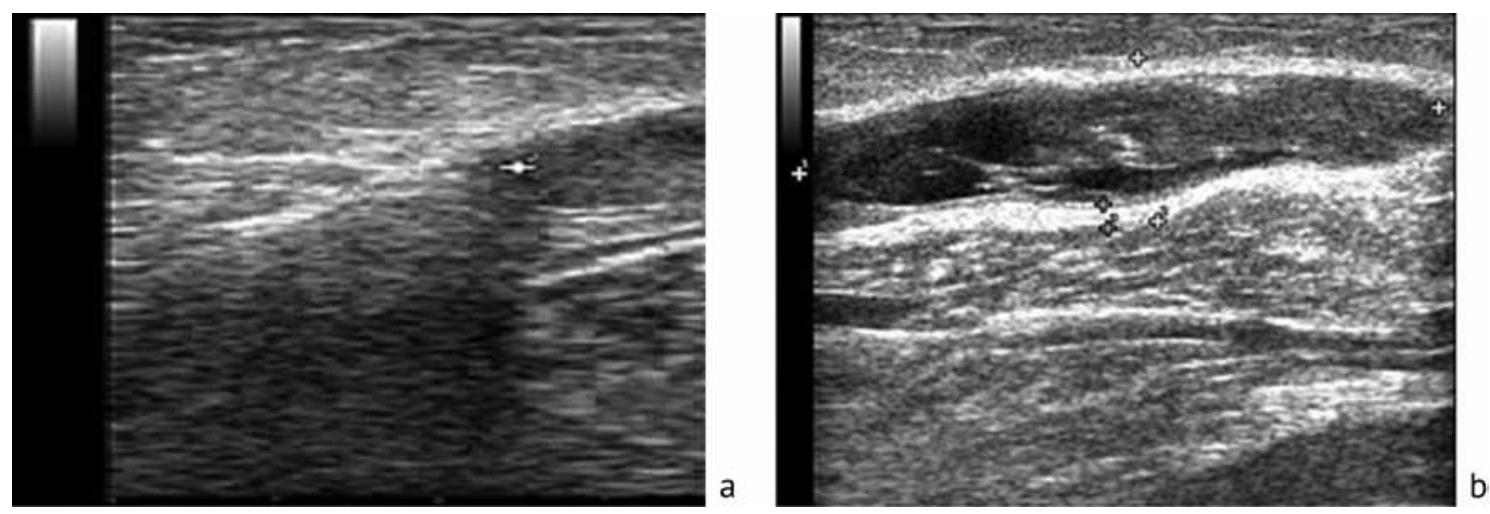

Fig. 1 Baker's cyst prior to laser induced thermal therapy visualized with (a) ultrasound transverse scanning and $(\boldsymbol{b})$ ultrasound transverse scanning

The procedure was performed on November 6, 2017 at a manipulation room with local anaesthesia (lidocaine $2 \%-2.0$ ) maintaining the intervention aseptic. The cyst was directly drained by aspiration with a needle. A 600 -mom thick quatrz light pipe was inserted în the mass cavity via lumen of aspiration needle. Ultrasound guided tumescent anesthesia (lidocaine $0.25 \%$ - 30.0) was performed. Anesthetic solution was injected în perifocal tissues above and below the entity. The power of the laser beam was set at $10 \mathrm{~W}$ with beams being continuous. A session of ultrasound-guided laser-induced thermal therapy lasted for 150 seconds at 1508J. There were difficulties with visualization of the light pipe butt at the return traction of optical fiber that resulted in 20-to-30-second radiation exposure of subcutaneous adipose tissue infiltrated with anesthetic solution. Thermal injury to skin could be seen after the procedure (Fig. 2). INTRASITE ${ }^{\mathrm{TM}}$ gel and aseptic dressing were applied shortly for the burn.

The patient was recommended to use 20-minute local cryoapplications three times per day, diclofenac $50 \mathrm{mg}$ twice a day and retain dressing to 09.11.17. Visual inspection of 09.11.17 revealed moderate swelling and infiltration of soft tissues around the sinus opening formed at the site of aspiration with scanty seropurulent discharge. Ultrasound examination showed hypoechoic mass with spiculated margins and internal heterogeneity with no capsule. The entity sized $552 \times 20 \times 15 \mathrm{~mm}$. Increased echogenicity was noted în the soft tissues around the mass (Fig. 3).

Aseptic dressing was applied after the wound had been treated with furacin. The patient was recommended to continue use of NSAID with a 7-day follow-up visit. She presented with no complaints at a week follow-up. Sinus could still be visualized and seropurulent discharge noted. Edema, infiltration and hyperemia were shown to subside but appeared to focus around the sinus with palpable fluctuation. Abundant necrotizing soft tissues exuded from the sinus at compression of the infiltration (Fig. 4a). The microscopic examination revealed clumps of stabs and a slight tissue component (Fig. 4b).

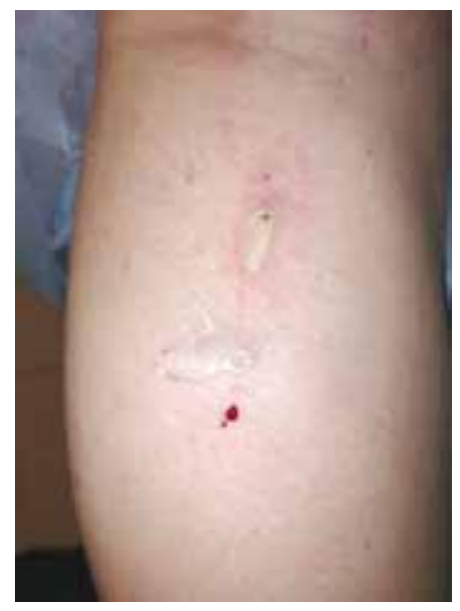

Fig. 2 Photograph showing popliteal area behind the left knee in a 51-yearold female patient $\mathrm{R}$. who underwent intervention on 06.11.17. Gel spread over the burn surface can be seen în the picture taken immediately after the intervention
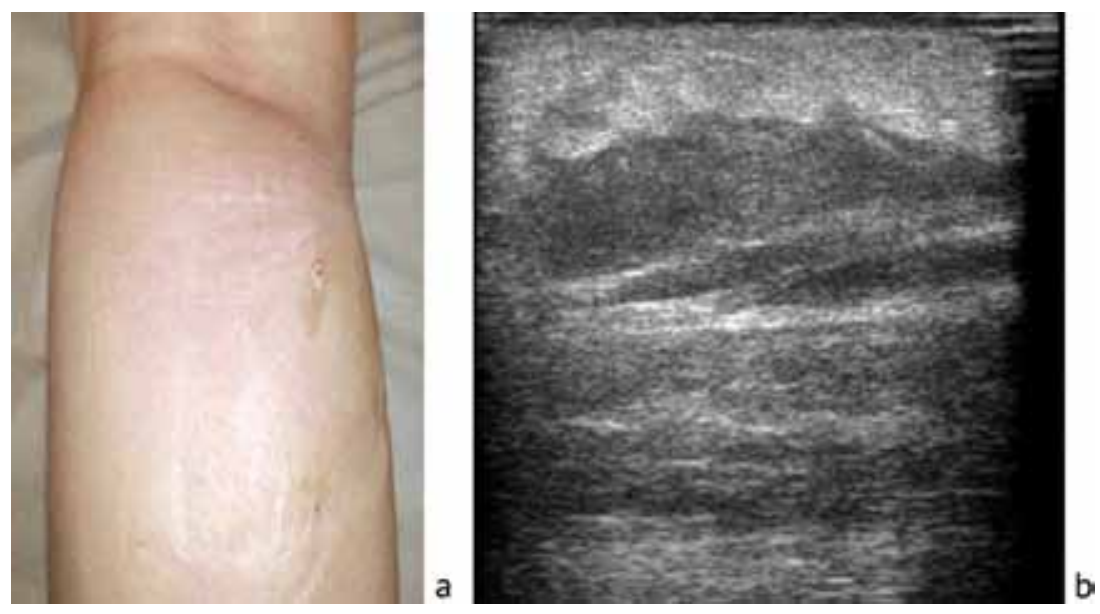

Fig. 3 Local examination performed on 09.11.17 demonstrating (a) popliteal area behind the left knee with point sinus at the site of aspiration; (b) ultrasound scan of the popliteal space behind the left knee showing soft tissue infiltration at the site of thermal therapy 

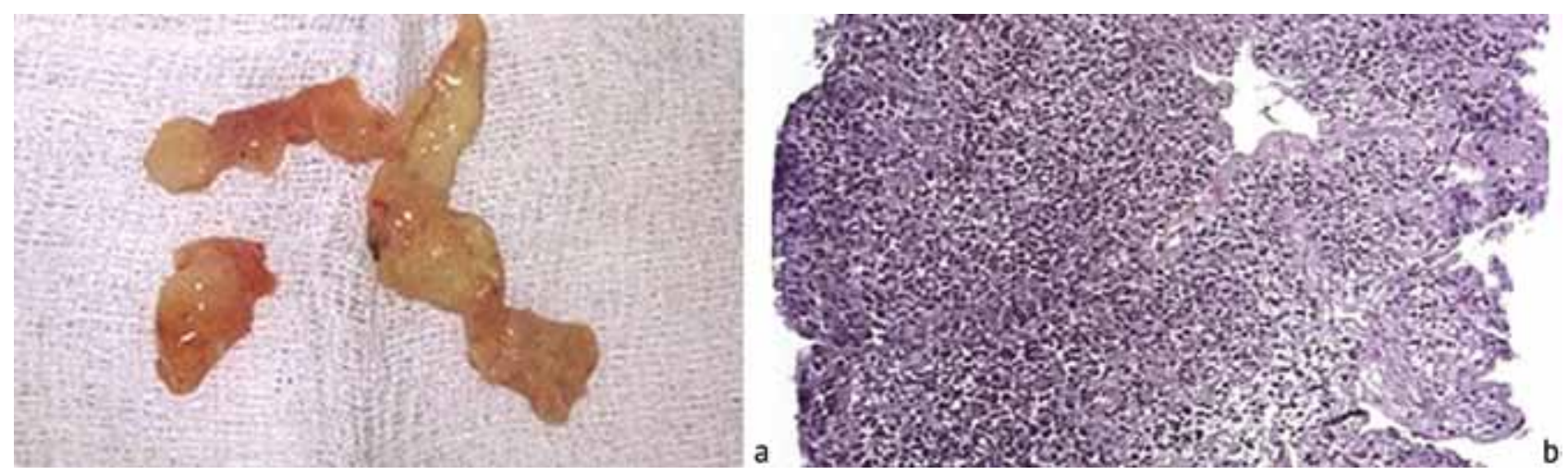

Fig. 4 Photograph of discharge from the sinus 7 days after manipulation demostrating $(\boldsymbol{a})$ necrotic masses exuded from sinus; (b) micropreparation of nectrotic masses. Stained with hematoxylin and eosin. Magnification $\times 100$

Sinus tract and the cavity în subcutaneous cellular tissue were debrided with $3 \%$ hydrogen peroxide solution, followed by application of levomekol ointment and aseptic dressing. Outpatient recommendatons included levomekol ointment dressings to be applied every other day and NSAID to be continued for 10 days with no antimicrobial therapy. Follow-up visit was scheduled în a month postsurgery.

The patient presented with no complaints at a 38day follow-up and had no signs of edema, hyperemia and infiltration. The cavity în subcutaneous cellular tissue obliterated and the sinus epithelized with signs of hyperpigmented skin around. Ultrasonographic scan showed decrease în hyperechogenicity of injured tissues with infiltration having heterogeneoushyperechogenicity and sized up to $38 \times 10 \times 8 \mathrm{~mm}$ (Fig. 5).

The patient reported no complaints at a 3-month follow-up, maintained good range of motion în the knee joint with no signs of vascular and neurological disorders în the left lower limb. Only a nidus of hyperpigmented skin could be locally observed (Fig. 6). Ultrasound examination showed a small nidus of prolate hypoechoic structure without liquid that sized $30 \times 4 \times 2 \mathrm{~mm}$.

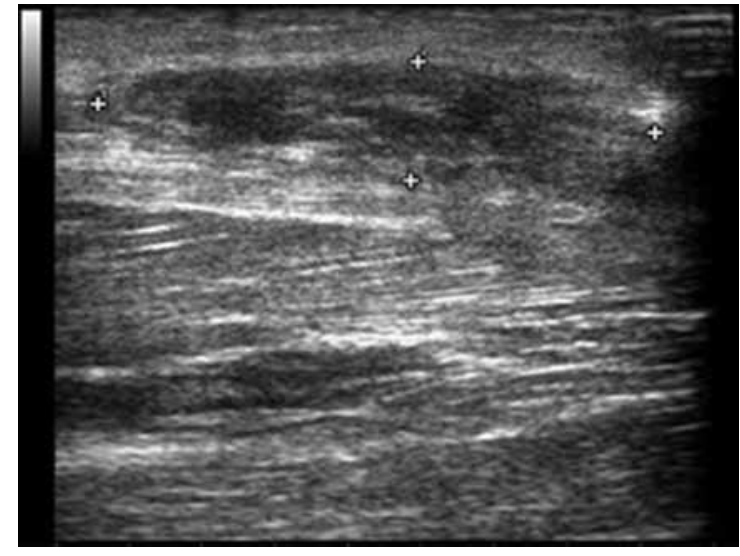

Fig. 5 Ultrasound examination of popliteal area performed on 14.12.17 showing infiltration în soft tissues with normal echostructure regained

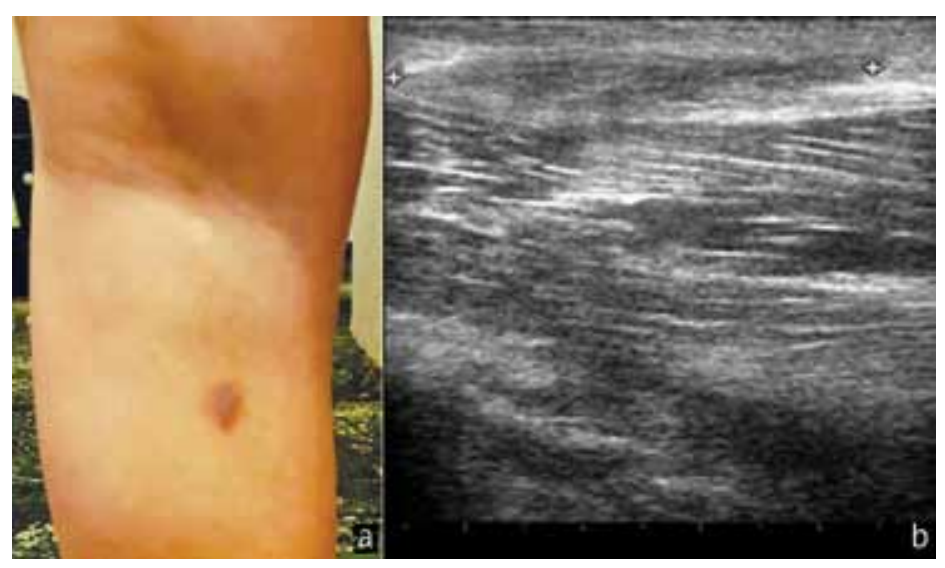

Fig. 6 Physical examination of popliteal area at a 3-month followup on 02.02.18 demonstrating $(\boldsymbol{a})$ the sinus being completely obliterated. A nidus of hyperpigmentation is seen at the aspiration site; (b) US scan of soft tissues showing the site of thermal therapy. Baker's cyst is not visualized with infiltration regressed

\section{DISCUSSION}

We do not consider tumescent anesthesia an optimal solution for laser induced thermal therapy of Baker's cyst for several reasons. First, surrounding tissues of the subcutaneous fat saturated with water solution of local anesthetic contribute to higher hydration and capacity to absorb radiation at wavelength of $1.47 \mathrm{mcm}$ resulting în considerable overheating effect. Second, tumescent anesthesia fails to provide substantial anesthetic effect because major pain receptors of the cyst wall are located în the medium layer, close to capillary net and the solid external cyst wall prevents lidocaine diffusion [7]. Third, this type of anesthesia tends to squeeze cystic tissues to the light pipe în a heavy erratic manner and can lead, on the one side, to the light being completely absorbed by tissues with local temperature sharply increased to the point of carbonization. On the 
other side, direct photocoagulation effect can occur at an area being equal to the width of the light pipe butt and the length of its trajectory in return traction from Baker's cyst. This is not enough for the total or subtotal coagulation of the collagen comprising the popliteal cyst wall.

One should avoid unintentional exit of the acting light pipe butt beyond the external fibrous layer of Baker's cyst. The occurrence can be visualized on the ultrasound screen and if happens, the laser induced procedure is to be immediately terminated. A 20-minute cryoapplication can be helpful after use of aseptic dressing.

Patients should be given special consideration when treating laser induced burns with tissues having been sujected to thermal injury and photon beam radiation inducing cell apoptosis. This factor interferes with the regenerative capabilities leading to granulation. Therefore, we would not advocate classical extensive incisions to drain infiltrations developing at the site of subcutaneous laser induced burns.

Funding. The findings are a part of the Start research project supported by Federal State Budgetary Institution „The Foundation for Assistance to Small Innovative Enterprises in Science and Technology" (Innovation Promotion Fund).

Acknowledgements. The authors would like to thank S.Yu. Medvedeva Cand. Sci. (Med), leading researcher at the Institute of Immunology and Physiology UB RAS for her assistance in histological studies and thorough description of histological characteristics of specimen.

Competing interests. The authors have declared that no competing interest exists.

\section{REFERENCES}

1. Herman A.M., Marzo J.M. Popliteal cysts: a current review. Orthopedics, 2014, vol. 37, no. 8, pp. e678-e684. DOI: 10.3928/0147744720140728-52.

2. Morozov S.P., Ternovoi S.K., Gorodnichenko A.I., Artsybasheva M.V., Filisteev P.A. Magnitno-rezonansnaia tomografiia v diagnostike povrezhdenii i zabolevanii kolennogo sustava [Magnetic resonance tomography in the diagnostics of the knee injuries and diseases]. Kremlevskaia Meditsina. Klinicheskii Vestnik, 2014, no. 2, pp. 58-62. (in Russian)

3. Zhou X.N., Li B., Wang J.S., Bai L.H. Surgical treatment of popliteal cyst: a systematic review and meta-analysis. J. Orthop. Surg. Res., 2016, vol. 11, pp. 22. DOI: 10.1186/s13018-016-0356-3.

4. Shakhno E.A. Fizicheskie osnovy primeneniia lazerov $v$ meditsine: ucheb. posobie [Physical foundations of using lasers in medicine: study guide]. Spb., NIU ITMO, 2012, 266 p. (in Russian)

5. Cherniadev S.A., Chernookov A.I., Zhiliakov A.V., Korobova N.Iu. Ispolzovanie ultrazvukovogo metoda dlia kontrolia vypolneniia interventsionnoi lazernoi obliteratsii kisty beikera i otsenki ee blizhaishikh rezultatov [Ulrasound method use to control performing the intervention laser obliteration of Baker's cyst and to evaluate its immediate results]. Radiologiia-Praktika, 2015, no. 3, pp. 2428. (in Russian)

6. Sokolov A.L., Liadov K.V., Lutsenko M.M. Lazernaia obliteratsiia ven dlia prakticheskikh vrachei [Laser obliteration of veins for practiotioners]. M., Medpraktika-M, 2011, 136 p. (in Russian)

7. Medvedeva S.Iu., Diachkova G.V., Diachkov K.A., Migalkin N.S., Maltseva L.V. Vozrastnye, ultrazvukovye i gistomorfologicheskie osobennosti kisty Beikera [Age-related, ultrasound, and histomorphologic features of Baker's cyst]. Zhurnal Anatomii $i$ Gistopatologii, 2018, vol. 7, no. 2, pp. 44-49. (in Russian)

Received: 06.05.2019

Information about the authors:

1. Sergey A. Chernyadiev, M.D., Ph.D., Professor, Ural State Medical University, Ekaterinburg, Russian Federation,

Email: chsa-surg@mail.ru, https://orcid.org/0000-0003-4207-1862

2. Vitaliy B. Aretinskiy, M.D., Ph.D., Professor, Honored Health Worker of the RF,

State Autonomous Health Institution of the Sverdlovsk Region „Chusovsky Lake” Regional Specialized Centre of Medical Rehabilitation, Ekaterinburg, Chusovsky Lake Settlement, Russian Federation,

Email: priemnaya@chuslake.ru, https://orcid.org/0000-0002-6063-5206

3. Andrey V. Zhilyakov, M.D., Ph.D.,

New Technologies for Outpatient Medicine Ltd. (“NOTAMED” LTD), Ekaterinburg, Chusovsky Lake Settlement, Russian Federation,

Email: doctor-zhilyakov@rambler.ru, http://orcid.org/0000-0003-1261-3712

4. Natal'ja Yu. Korobova, M.D., Ph.D.,

Ural State Medical University, Ekaterinburg, Russian Federation,

Email: olvin.phlebolog@mail.ru, http://orcid.org/0000-0002-8523-912X

5. Sergey M. Kutepov, M.D., Ph.D., Professor, Corresponding Member of RA Sciences,

Ural State Medical University, Ekaterinburg, Russian Federation,

Email: usma@usma.ru 